\title{
HIGHER EDUCATION OF UKRAINE PLAGUED BY THE COVID-19 PANDEMIC
}

\author{
S. Grynyuk ${ }^{1}$, A. Zasluzhena ${ }^{1}$, I. Zaytseva ${ }^{2}$, I. Liahina ${ }^{3}$ \\ ${ }^{1}$ National Aviation University (UKRAINE) \\ ${ }^{2}$ Kyiv National University of Trade and Economics (UKRAINE) \\ ${ }^{3}$ Borys Grinchenko Kyiv University (UKRAINE)
}

\begin{abstract}
At present, the world is adjusting to a new reality. The Coronavirus Pandemic (COVID-19) has altered every aspect of public life, introducing abrupt changes to the way governments, businesses, and communities operate. In the sphere of education, there have been taken immediate steps by education systems to reduce the negative impact of the COVID-19 pandemic on the branch.

The Ministry of Education and Science of Ukraine, its subordinate departments and offices are also trying to minimize losses from coronavirus in the field of education by taking necessary measures to combat and stabilize the situation in the country. The Heads of educational establishments, educators, teachers, as well as students and their parents began to adapt rapidly to new learning conditions, mastering various forms of distant interaction.

The aim of this article is to present a scientific analysis of higher education potential in Ukraine by providing the educational services in the quarantine period caused by the COVID-19 pandemic. The study will summarize the basic principles of inner state policy in the sphere of education, measures taken to combat the negative influence of the pandemic on the branch, and distant learning solutions that are capable of ensuring quality education and overcoming the negative consequences of the pandemic in Ukraine.
\end{abstract}

Keywords: higher education, principles of state policy in the sphere of education, measures taken to mitigate the negative impact of the pandemic on education, distant learning solutions in Ukraine.

\section{INTRODUCTION}

Today, the world community is experiencing a complex and contradictory period of social transformations and systemic challenges, marked by many dramatic conflicts. Among the most urgent there has been a fight against the COVID-19 pandemic, which affected most countries and virtually all spheres of public life. Of course, this is a new reality for all the humankind which complicates the implementation of plans and forecasts for the future.

Consequently, one of the ways to deter and resist coronavirus infection came to be social isolation which required partial or complete closure of educational institutions and related infrastructure. As a result, more than 1.5 billion students (pupils and students) worldwide (91.3\% of the total number of pupils and students) were cut off from their schools and universities. Education leaders from all over the world almost simultaneously faced a difficult choice: whether to try to transfer educational processes to the distant mode of operation or to suspend the educational activity temporarily [1].

Ukraine is not exclusion. It is also experiencing the same difficulties and problems in education due to the coronavirus pandemic as other countries and, thus, requires all state structures to make responsible and correct decisions. The Ministry of Education and Science of Ukraine, its departments and offices are trying to minimize losses from coronavirus in the field of education. A number of steps have been taken to stabilize the situation, the most important of which is the transition to distance education in the quarantine period for schoolchildren and students [2].

The purpose of this article is to conduct a comprehensive scientific analysis of higher education potential in Ukraine to provide educational services in conditions of global destabilization caused by the COVID-19 pandemic; the study will summarize current principles, distant learning solutions and measures to combat the negative influence on the educational system of Ukraine, its sector of higher education in particular, taking into account all the conditions the COVID-19 pandemic crisis has accelerated. 


\section{METHODOLOGY}

The COVID-19 pandemic determined the need of a scientific understanding of the nature of this phenomenon, the search for a new conceptual apparatus that must correspond to a radical change in the way of life of mankind and the functioning of social institutions. There is an obvious lack of traditional approaches to understanding the issue and there is an urgent need to form a new scientific understanding of the transformation of the world community in a pandemic as a global phenomenon.

It is worth to be mentioned that there is a search for new theoretical and methodological foundations of scientific understanding of the world, and this applies primarily to dialectics, systems analysis, personal approach, laws and principles of natural, technical and human sciences, including pedagogical and psychological sciences, which are directly involved in solving this problem.

In our research we consider the use of a set of theoretical and empirical methods to solve the defined tasks and achieve the goal. Theoretical: comparative method will make it possible to characterize the current state of the educational process in Ukraine compared to the world systems; it will identify strategic priorities, key approaches to the effective implementation of educational activity by higher education institutions in quarantine and the level of students' psychological readiness to study in times of global instability; interpretation-analytical method will be used for studying Ukrainian sources with the use of synthesis, analysis, systematization; methods of theoretical systematization, classification and generalization will contribute to the formulation of generalized conclusions; empirical (pedagogical experiment, observation, measurement, interview): focused on achieving the goal of the research. The proposed methods, complementing each other, will provide an opportunity for comprehensive knowledge of the subject.

The above mentioned methods are unlikely to coincide with traditional methodological and experimental canons, as the situation is extraordinary. However, methods of theoretical analysis and generalization of numerous psychological facts, in particular, statistical data and data from sociological surveys, taking into account personal and professional experiences during the pandemic, can also become important.

\section{RESULTS}

\subsection{The current state of the educational process in the field of higher education in Ukraine in new social realities}

It is obvious that the pandemic has become a kind of catalyst for rapid changes in the field of education in Ukraine. Public authorities, heads of educational establishments, lectures/teachers, as well as students, pupils and their parents began to adapt rapidly to new learning conditions, mastering various formats of distant interaction. As a result, experts' debates about how and when digital technologies will change the face of modern education, how they will affect the general perception of learning and, of course, how the current education system will respond to the digital challenge have been brought to naught.

Ukrainian government, professional organizations, and business representatives have joined forces to build the educational process with all available means, trying - literally "on the fly" - to reduce the degree of serious digital inequality. Therefore, practices of transforming full-time education into distance learning formats have been hastily introduced [3; 4].

At present, a robust list of distance-learning solutions is used to provide the educational process in a distant format in Ukraine: 1) resources that provide psychosocial support for participants of educational relations in a pandemic; 2) digital learning management systems (Google classroom, Moodle, Blackboard, Canvas); 3) programs for learning on the basis of mobile devices; 4) programs with advanced offline functionality; 5) mass open online courses (MOOCs); 5) self-study services; 6) electronic readers; 7) programs that provide the opportunity of working together online (Skype, Zoom, WebEx); 8) tools for creating digital educational content and numerous electronic databases of educational materials [5; 6].

However, despite a fairly wide range of available technologies, even the leading countries, not to 
speak of Ukraine, in the field of digitalization of the economy (the USA, China, and Japan) have experienced significant difficulties in implementing distance learning. The biggest barrier in Ukraine, we assume also worldwide, was not so much the lack of infrastructure or unwillingness of lectures/teachers to master certain technologies of digital learning, as the fact that the current situation

2914

has radically changed the established models of social interaction. There was a generation gap. Communication between students and teachers has moved to a new format. In some cases, in those families, in which all their members had often to participate in the learning process, there was observed an increase of emotional pressure. For many families, the lack of the so-called "doses of school / student doping" among young people, has become a vital problem. Accelerated "digitalization" has become, in a way, a test of the strength of students, teachers, schools, national educational systems, and, most importantly, the ability of humanity to cooperate in the situation of great challenges.

Taking into account the complexity and drama of the situation, it should be noted that a new reality is a unique opportunity for the Ukrainian education system, and not only, to make self-diagnosis under hard circumstances. Ukrainian educational institutions are eager to test the effectiveness of the proposed digital solutions, determine their needs for technological modernization, and if necessary, consider the organization of retraining and additional training of teachers [6].

Perhaps today the most favourable conditions for comprehensive development strategies evolved in Ukraine and worldwide. A certain "slack" caused by temporary isolation allowed us - Ukrainians- to look anew at what can be considered the core of modern education, better understand what tasks we set for in the near future and, most importantly is to answer the question: "Is it necessary to shift totally to "digital education" or not?

\subsubsection{Distance learning solutions in Ukraine to ensure quality education and overcome the negative consequences of the pandemic}

The transition to distance learning, due to the pandemic, has become an unexpected and quite serious challenge for all participants in the educational process (the administration of higher educational institutions, teachers and students). After a temporary confusion, all players had to accept this challenge and quickly adapt to new realities. And although distance learning is not a substitute for full-time education and was never planned for the long term, it has become a vital tool during quarantine in Ukraine and the world at large. Therefore, teachers should be prepared to organize such training because it is unknown how the epidemiological situation in Ukraine will change soon.

This part of an article is somewhat a snapshot of some of the measures taken by the Ukrainian government to address their immediate challenges. The information is based on various sources, including government announcements, official documents, decrees, circulars and guidelines, as well as media reports.

The list of educational platforms and resources, we are going to rely on in this study, are used by the Ukrainian education system. They help students, teachers, universities/schools, parents, and university/school administrators facilitate student learning and provide social care and interaction during periods of university/school closure. Most of the solutions are free and many cater to multiple languages; they have a wide reach, a strong user-base and evidence of impact. They are categorized based on distance learning needs, but most of them offer functionalities across multiple categories.

There is no doubt that there is a big difference between comprehensive distance learning and distance learning forced by quarantine - "compulsory quarantine training". During the last one in Ukrainian higher education institutions, lectures, seminars and consultations were held by videoconference using external platforms Microsoft Teams, Zoom, BigBlueButton, Skype, Google Classroom, etc. For video conferencing, each teacher independently created a virtual room (classroom) on the appropriate platform and invited students to participate in it.

The peculiarity of the compulsory quarantine training in Ukraine was that teachers and students had to master in a short time a single virtual system in which they had to work. The criterion for selecting a modern distant-oriented software product is the integration within one computer program of the main tools of distance communication, namely: the ability to quickly share files; support of voice and video communication for group seminars, conferences or individual consultations; integrated testing system; the presence of a chat for operational communication with the teacher or curator; work on Android or 
iOS mobile platforms; intuitive interface that does not cause difficulties in its study; the minimum number of technical means to ensure the distance learning process.

Many Ukrainian universities have used corporate services for online learning, such as Google Meet, Google for education. For example, in NAU the learning process was carried out on the basis of GoogleSuite for education through a corporate account with free access to the Google services package for learning (Classroom, Sites, Gmail, Google Vault, Groups for Business, Hangouts Chat,

2915

Hangouts Meet and Google Hangouts, Jamboard Service, Keep, Google Drive, Google Chrome Sync).

Borys Grinchenko Kyiv University (GrKNU) and Kyiv National University of Trade and Economics (KNUTE) used Microsoft Teams as their core and some teachers used Moodle, Zoom, Viber. Moodle was used at the Kyiv National Linguistic University (KNLU).

MS Teams is an online service that has a set of tools (chat, notes, video conferencing) to support teamwork, including distance learning. With MS Teams, it is easy to conduct online lectures in the form of virtual meetings, send files and assignments to students, give presentations and hold discussions.

After analyzing the work in the Teams system with students during quarantine, we can state that this software product has many advantages that determine the prospects of using this program in the distance learning process, namely: the program integrates all the necessary tools for the implementation of the distance learning process; the application is available on iOS and Android mobile platforms; familiar to most users formats for working with text files. Educational and methodological support of the course, individual tasks and options are saved and loaded into the system in doc and docx format; flexibility and simplicity in the administration of the educational process.

The Moodle platform contains a large number of different learning modules that provide communication between teacher and students. With the help of the platform, the teacher can choose any of the modules, place it on the site, edit, update, create training courses; use it to inform, teach and evaluate students. The platform allows monitoring student activity, contains a user-friendly electronic journal of grades.

It should be noted that before the quarantine period, Ukrainian scientists presented works on the experience of using the integration of Google Apps cloud services in the information and educational space of higher education institution [7], analysis of opportunities and benefits of using cloud services G Suite (Google Apps) during student practice [8], the use of Google's cloud technologies and Web-2 services in the educational process [9]. However, these investigations were not widespread. We do not take into account those scientists whose professional activities are related to distance learning.

Moreover, in the conditions of the compulsory quarantine period was a problem in the methodologically competent organization of the educational process. The platforms GoogleSuite for education, Microsoft Teams and Moodle allow implementing the following didactic principles: activity, illustrative purpose, awareness, accessibility and individualization.

Google Classroom provides the principle of interactivity through the systematic implementation of control with an unlimited number of times, the definition of control objects for the selection of adequate forms of control, excluding the subjective factor in the teacher's assessment [10], which also characterizes Microsoft Teams and Moodle platforms. The responsibility for ensuring the principle of potential excess of educational information relies entirely on the teacher. The teacher needs to elaborate the task in the way to involve the students' reflective activity and activate their cognitive processes [11].

During the compulsory quarantine, teachers acquired somewhat a new experience. They created virtual classes and invitations for students, downloaded tasks, conducted practical classes in the format of online meetings, developed tasks methodically correct, created tasks for student assessment.

To overcome the negative consequences of the pandemic the Ministry of Digital Transformation of Ukraine has launched a free online course for teachers to organize distance learning during quarantine, Ukrainian and foreign educational platforms (for example, Prometheus, iLearn, Coursera edX, Coursera for Campus and others) provided free access to their courses. 
The experience of work in new social conditions also demonstrated that in distance learning, as the initial experience of teachers has shown, such pedagogical technologies of face-to-face learning as: technology of problem learning, technology of project learning, technology of development of critical thinking, technology of research learning, technology of individualized learning can be successfully used. However, some adaptation to distance mode and appropriate training of teachers is required.

2916

\subsubsection{Diagnosing the level of psychological readiness of high school students to study in the quarantine conditions}

Education authorities in the 50 member states of the European Cultural Convention are faced with the task of minimizing the impact of the crisis related to the COVID-19 pandemic on students. The concept of distance education development in Ukraine and Regulations on Distance Learning state that educators in the process of implementing distance learning should take into consideration information about students' psychological readiness to study under the conditions of quarantine.

Psychological readiness is defined as a result, a state, a consequence of a person's professional training in one or another type of activity [12]. Due to our study we consider psychological readiness to be one of the key factors in the successful implementation of distance learning that contains a set of knowledge, skills, personal qualities, motives to adapt to working conditions, which influences the performance, promotes to the professional and personal development.

In order to diagnose the level of psychological readiness of high school students to study under the conditions of quarantine, we conducted the research. The main method of the conducted research was a survey. It took place in the academic year of 2020. The main goal of the survey was to identify the level of psychological readiness of high school students to study under the conditions of quarantine as well as to determine various distractions (due to lack of teacher control over the situation) [13], the obstacles and difficulties that the students can arise. In the process of online learning the situations that block the cognitive activity and creative self-expression of the students can arise. We call such situations psychological difficulties, or "psychological barriers" or obstacles (in psychology it means a kind of human reaction to the barrier itself). They relate to the lack of motivation, the fear of making a mistake, low self-esteem, the process of adaptation to distance learning and anxiety [14].

The survey was held among the high school students learning English at four Ukrainian universities. The bar chart below "Fig. 1" shows the proportion of the Ukrainian university students taking part in the inquiry. It comprises four universities from Ukraine: Borys Grinchenko Kyiv University (GrKNU) 75 students), Kyiv National Aviation University (KNAU) 78 students), Kyiv National Linguistic University (KNLU) 180 students), Kyiv National University of Trade and Economics (KNUTE) 155 students). Overall, the total number of the respondents was 488 .

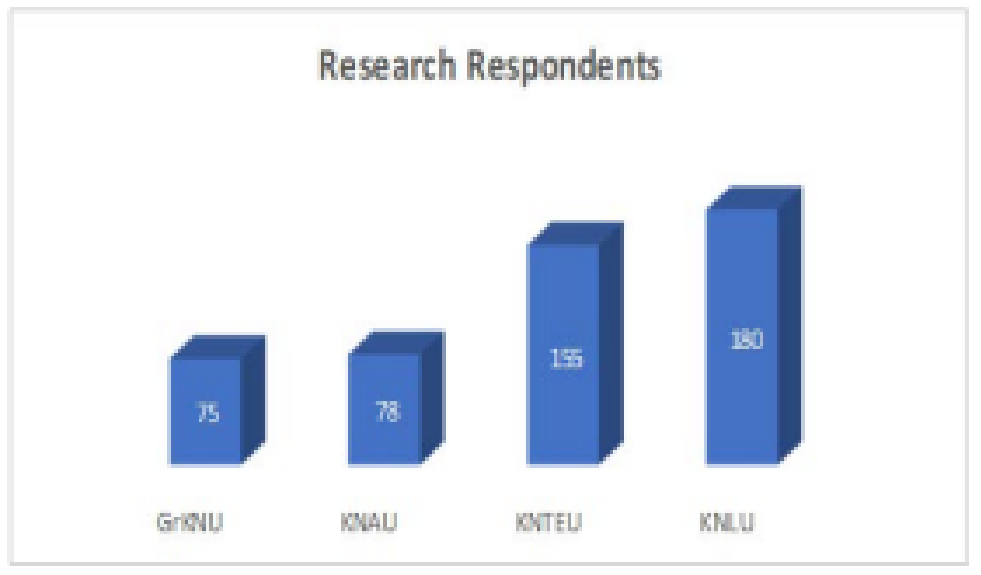

Figure 1. Research respondents in four Ukrainian universities 
The questionnaire reveals students' readiness for distance learning. According to the results of the survey students (62\% of respondents) believe that their level of psychological readiness to study under the conditions of quarantine is low. However, a high number $(81.7 \%)$ of respondents is positive about distance learning. The interpretation of the above data suggests that high school students have a high motivation for distance learning but the majority of respondents find it difficult to learn English due to their low level of psychological readiness to study under the conditions of quarantine.

$39 \%$ of students think that distance education will not replace face-to-face learning while $47 \%$ of students indicate a partial replacement. And $23 \%$ of students consider distance education to be an appropriate substitution for traditional face-to-face learning.

2917

In students' opinion, there are several factors which affect their level of psychological readiness to study under the conditions of quarantine: various distractions and psychological difficulties. $78.7 \%$ of students note that they have insufficient experience studying online. In addition, $58 \%$ of respondents lack social interaction between students. Besides, students feel uncomfortable not being able to see and communicate directly with the lecturer and other students. $64 \%$ of students need to take measures to discipline and organize themselves to study online. The feeling of isolation with no physical social interaction with their lecturer and groupmates affects the level of students' psychological readiness $[15,646]$. Students' lack of self-discipline and lower level of motivation can affect their academic performance and achievements. $81 \%$ of students note that feedback from their educators; individual consultations and assessment motivate them to study, especially under the conditions of quarantine.

According to students' opinion (57\%), distance education significantly influenced the planning process of their self-study work, Moreover, $52 \%$ of respondents note that they face such psychological difficulties as immersion of self-anxiety, emotional detachment in communication, lack of empathy, and self-centeredness.

$62 \%$ of students think that distance learning under the conditions of quarantine has great impact on the development of their time management skills as most of them simultaneously combine study and work. However, $56 \%$ of respondents note that they still have difficulties in planning their time in comparison with the previous period. $54 \%$ of students have reported that they have learned to manage their time in comparison with the previous period.

The results of the survey also show that the reason for students' difficulties in learning, lack or low level of motivation and decreased interest is largely due to the inability to organize and carry out self study work, plan their time properly (83\%). Thus, students would like to be able to receive teacher assistance during the learning process in case of difficulties. $34 \%$ of respondents have difficulties with the perception of information from the electronic display, $24 \%$ of students note that they have problems to organize the place for to study without external distractions (noise, other family members etc.).

$67 \%$ of respondents state that get tired in the process of distance education very quickly. The "effect of technology overload" is that a person is not able to perform monotonous tasks without changing his activity for even a short period of time. In addition, the focus on technical means and tools, on the virtual environment, constant concentration on the computer display affect the emotional state of students. New conditions of studying in quarantine put forward a number of specific requirements: the ability to perceive and choose important information from a large information flow, the ability to briefly create messages or requests, the ability to properly distribute loads.

Let us consider the students' views on the relevance of the psychological problems arising in the process of distant learning under the conditions of quarantine. All these problems are the key factors that affect the psychological readiness of students to study under the conditions of quarantine "Fig. 2".

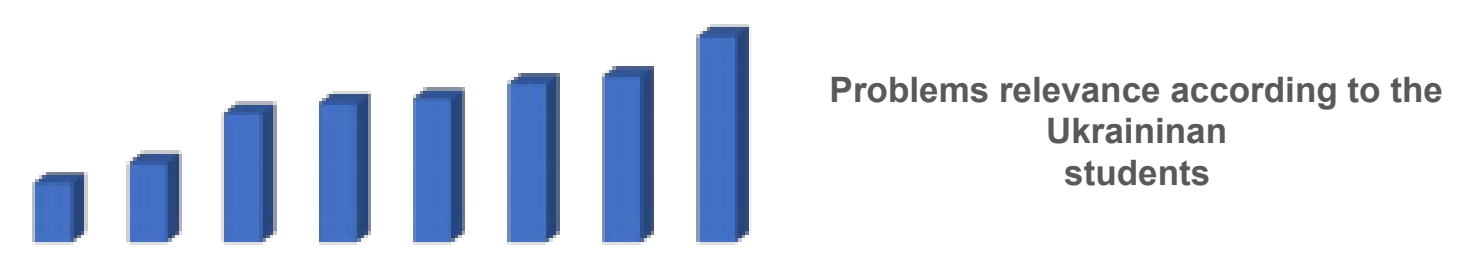




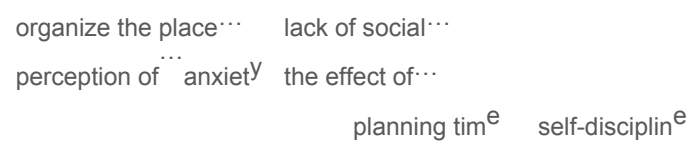

Figure 2. Problems relevance according to the Ukrainian students

According to the results of the survey, the students have a low level of organizational skills, so educators should help students to develop such skills and the skills mentioned above. A low level of

organizational skills can be explained by such psychological problems as lack of experience of independent work, lack of ability to self-regulate one's motivation. It can also be related to the individual characteristics of the learner, for example, to the dominant way of information perception, and so on.

Psychologists emphasize the student's ability to work independently with information, because independent work is a key component of psychological readiness to distance learning. There are the following levels of psychological readiness of a student for independent work:

- high, when the cognitive, professional motives prevail;

- intermediate, when there are different motives, caused by different problems; - low,

when the external motives prevail, for example, the need to pass a test or exam.

The leading motives of independent activity can be educational - cognitive and professional motives. Specific motives can be interests, responsibilities, fear of being expelled from the higher educational establishment, and so.

The level of motivation is one of the key factors for the psychological readiness to study [14]. The higher the level of motivation is the more interested is the speaker in the discussion and in its results. In the process of learning the motive rarely occurs by itself, it must be created with the help of an interesting topic and problem/controversial situations.

There are the following tasks of psychological support for distance learning: the study of the environment (and communicative environment as a set of individual characteristics of the participants), the study of personal characteristics, level of mental properties, the characteristics of interpersonal relations of participants of distance learning; transmission to distance learning participants relevant information on psychological issues; creating the most favorable conditions for the development of the necessary personal qualities of the students and the teachers during the learning process and their full adaptation to training conditions; providing individually-differentiated approach to teaching, based on the psychological characteristics of the students to overcome the often dominant authoritarian style in teaching [16].

These findings must be taken into account conducting the further researches devoted to the problem of distance learning under the conditions of quarantine as well as during the process of organizing distance learning for high school students.

\subsection{Problems and prospects of current and future transition to distance learning}

The key areas of research on the readiness of higher education subjects (students, teachers, higher educational institutions) to distance learning under quarantine and the impact of new conditions of education on the educational results of students are [17]:

- Readiness of universities for the transition to distance learning.

- Readiness of students' families to the changed conditions of education in the distance mode.

- Readiness of teachers to organize distance learning in the mode of self-isolation. - Quality of education in the transition to $100 \%$ distance learning. 
The analysis of the opinions of the survey participants about the existence of conditions for distance learning in universities showed that the awareness of necessity and the real situation in universities differ significantly. About $70 \%$ of respondents who participated in the all-Ukrainian survey actually pointed to an imbalance between the necessary conditions that they believe should be created in universities for the implementation of distance learning and the real university situation. $30 \%$ of respondents indicated that they did not have any university facilities: stable and sustainable Internet connection, a teacher's workplace; sufficient number of activities for methodological support of teachers in conducting distance learning. Moreover, a system of methodological support is one of the determinants of teachers' readiness. Only $62.2 \%$ of teachers receive such assistance in the form of master classes, webinars, consultations, etc.

In the context of our survey, it was important to find out how the equipment at the teacher's workplace is used. There is a problem to provide teachers with access to content resources and control and measuring materials in universities. According to the interviewed pedagogical workers, today an

2919

educational organization is not always able to provide full work and support of a teacher to implement quality online/distance learning in self-isolation.

According to the study, the effectiveness of distance learning is largely due to the motivation of teachers to actively interact with learners and use all available means of communication for this purpose. It turned out that only $3 \%$ of teachers considered high motivation for interaction with students as an optional condition. A significant proportion of teachers $(60 \%)$ considered this condition necessary, while $37 \%$ considered it desirable.

The survey of family readiness to distance learning showed that there should be created conditions in the students' families to implement quality distance learning. They are the following: stable and sustainable Internet connection; an equipped workplace for a student; access to educational online platforms with ready digital content for the performance of learning tasks.

However, the situation does not look very optimistic in reality. Only $22 \%$ of student families have stable Internet connection. This leads to interruptions of the distance learning activity periodically, irritating both students and the teacher. As a result, there is a loss of interest in learning and the learning material is not fully assimilated.

What is more, in the reasonable opinion of psychologists, the success of distance learning in self isolation is largely due to the involvement of parents in the learning process. And this applies to the distance learning lessons themselves, as well as to the performance of homework and then sending it to the teacher. Only $39 \%$ of respondents are definitely convinced of the need to include parents in the process of distance learning. $51 \%$ of respondents are not so categorical and believe it is desirable. $11 \%$ of respondents believe that parents do not have to participate in the educational process at all.

Since the success of any learning, including distance learning, is due to the level of emotional and psychological comfort of the subjects of education in the conditions of self-isolation, almost all respondents agree that in order to successfully implement quality distance learning, there should be create a favorable atmosphere in the families to encourage the organization and high student's motivation. However, based on the survey results, only $14 \%$ of families have created a favorable psychological atmosphere for distance learning. A little less was the percentage of families where there are no emotionally comfortable conditions for their children to study at home (11\%). In fact, in the majority of families some psychological difficulties preventing quality distance learning are noted.

The next point is the quality of distance learning that is greatly influenced by the motivation and organization of the learner. The majority of respondents $(67 \%)$ unequivocally believe that in order to receive quality online learning a student should be motivated and well organized. The study showed that older teenagers demonstrate a high level of independence, organization and motivation for home schooling.

The quality of learning in any format is directly dependent on the pedagogical technologies used by the teachers. Hereby, the teachers selected six currently most popular teaching technologies: problem learning technology, project-based learning technology, critical thinking technology, research-based learning technology, individualized learning technology, and group learning technology. They quite highly appreciated the possibility of using all the above mentioned technologies to face-to-face teaching for distance format and self-isolation conditions. At the same time, the technology of 
individualized learning (89\%) is considered the most promising by respondents. Only teachers had doubts about the technology of group learning. The possibility of using this technology in distance learning was seen by $60 \%$ of teachers.

At present, there are sufficient resources available in Ukraine for the implementation of major higher education programs in distance education. Moreover, their large number and diversity of preferences testify the fact that teachers are sufficiently free and independent in choosing platforms/resources for their work. At the same time, for the comfort and efficiency of students' learning activities, it is necessary to ensure the unity of requirements for online classes and teachers' approaches to organizing students' individual work within one university or one parallel course.

The last point is the teacher readiness to work in self-isolation mode. The transition to distance education was not a planned action but a forced measure, so there was no special training for teachers in this field. The adaptation of teachers to the changing professional environment is taking place at different speeds and with different results. But it must be recognized that mastery of competencies in the field of working with information resources helps teachers to move more easily to a new format of training.

2920

On average, about $15 \%$ of all teachers can not only perform most of their own functions using ICT, but also teach others to do so. More than $60 \%$ use most of the major tools currently available in the world to organize the educational process. More than $25 \%$ of educators are able to learn the necessary tools for organizing distance learning on their own when needed.

However, there is still a small percentage of educators who cannot even use basic tools for distance learning. The greatest difficulty is encountered by teachers in installing software, real-time collaboration programs, including the cases of work from home; collaboration with colleagues using common resources (e.g. Google Docs); use of learning computer programs, workshops, virtual laboratories; development of materials for evaluating learning achievements, monitoring student learning outcomes, creating tests, including using online services; participation in discussions in professional online communities; and participation in discussions in professional online communities.

It should be noted that $61 \%$ of teachers consider themselves able to work in the system of distance learning. And $15 \%$ of respondents can teach this to other teachers. It is also important that $34 \%$ of teachers believe that they can understand how to implement distance learning, and $5 \%$ of teachers will not be able to master information computer technologies. Thus, we can say that Ukrainian teachers have both motivation and a certain readiness to work in extreme conditions of distance learning and self-isolation.

\section{CONCLUSIONS}

Summing up the general results of the conducted research, the following conclusions can be drawn. Insignificant experience of using online technologies in Ukrainian universities in the mass transition to distance learning in the midst of the pandemic has led to objective difficulties and problems in organizing the educational process in a distant mode and self-isolation conditions.

The methodological and psychological readiness of educational subjects (managers, teachers, students and parents) for distance learning in quarantine and self-isolation conditions was insufficient

Difficulties and problems appearing in the process of distance learning are the key factors that affect the psychological readiness of students to study under the conditions of quarantine, they are the following: low level of motivation, the effect of technology overload, lack of self-discipline and social interaction, time planning, anxiety, perception of information, organizing the place to study.

One of the consequences of the transition to distance education was a significant overload of teachers, whose working hours actually increased, as well as difficulties in psychological adaptation of students to the distance education format, which can have a negative impact on their performance.

Teachers' problems in organizing distance learning include video lessons; the practice of using online resources; technical and organizational problems.

We have also found out that in distance learning such pedagogical technologies of face-to-face learning as: technology of problem learning, technology of project learning, technology of development of critical thinking, technology of research learning, technology of individualized learning can be 
successfully used. However, some adaptation to distance mode and appropriate training of teachers is required.

As one of the alternatives to overcome the temporary difficulties we see in creating the most favorable conditions for students and educators during the learning process and their full adaptation to training conditions; providing individually-differentiated approach to teaching, based on the psychological characteristics of the students. And, surely, a precondition for the development of distance learning should be a well-thought-out system of professional development and retraining of teachers, providing them with organizational and methodological assistance, including its distant and networked forms of organization, mentoring, exchange of good practices and experience.

\section{REFERENCES}

[1] UNESCO, COVID-19: 1.3-milliarda-uchashchihsya-nahodyatsya-na-karantine-v-svoih-domah-v vremya-kak ministry razshiryayt podhodu $\mathrm{k}$ distantsionnomy obycheniy dlya obespecheniya neprerivnsti obrazovania, Accessed 24 March, 2020. Retrieved from https://ru.unesco.org/ news/covid-19-13-milliarda-uchashchihsya-nahodyatsya-na-karantine-v-svoih-domah-v-vremya kak. (in Russian).

2921

[2] Verkhovna Rada Ukrainy, Ofitsiinyi vebportal parlamentu Ukrainy, Zakonodavstvo Ukrainy. Nakaz Ministerstva osviti i nauki Ukraïni "Pro zatverdzhennya polozhennya pro distancijne navchannya", Accessed 24 June, 2020. Retrieved from http://zakon4.rada.gov.ua/laws/show/z0703- 13/print1389899592029395 (in Ukrainian).

[3] Ministerstvo osvity i nauky Ukrainy, Vchymo i navchaiemosia na karantyni: zminy v systemi osvity, Accessed 20 June, 2020. Retrieved from https://mon-covid19.info/ (in Ukrainian).

[4] Blohy I. Likarchuk: pro orhanizatsiiu dystantsiinoho navchannia, Accessed 18 March, 2020. Retrieved from https://osvita.ua/blogs/71808/ (in Ukrainian).

[5] NAFI, Sistema obrazovaniya okazalas ne gotova k perehodu na distancionnoe obuchenie $v$ usloviyah pandemii, Accessed 4 April, 2020. Retrieved from https://nafi.ru/analytics/sistema obrazovaniya-okazalas-ne-gotova-k-perekhodu-na-distantsionnoe-obuchenie-v-usloviyakh pandemi/ (in Russian).

[6] S. Grynyuk "Innovative technologies in teaching a foreign language" Scientific Letters of Academic Society of Michal Baludansky, no. 7 (6A), pp. 78-81, 2019.

[7] V. P. Oleksiuk "Dosvid intehratsii khmarnykh servisiv Google Apps u informatsiino-osvitnii prostir vyshchoho navchalnoho zakladu", Informatsiini tekhnolohii i zasoby navchannia,vol. 35, Issue 3 , 2013. Retrieved from http://www.irbis-nbuv.gov.ua/cgi-bin/irbis_nbuv/cgiirbis_64.exe? I21DBN= LINK\&P21DBN=UJRN\&Z21ID $=\& S 21 R E F=10 \& S 21 C N R=20 \& S 21 S T N=1 \& S 21 F M T=A S P$ meta \& C21COM=S\&2_S21P03=FILA=\&2_S21STR=ITZN_2013_35_3_9 (in Ukrainian).

[8] O.H. Hlazunova, O.H.Kuzminska, T.V. Voloshyna, T.P.Saiapina, V.I. Korolchuk "G Suit for education yak seredovyshche dlia orhanizatsii navchalnoi praktyky studentiv", Informatsiini tekhnolohii v osviti, no. 2 (31), 2017. Retrieved from https://www.researchgate.net/ publication/321311264_G_SUIT_FOR_EDUCATION_AS_AN_ENVIRONMENT_FOR_STUDEN TS_OF_EDUCATIONĀL_PRACTICES (in Ukrainian).

[9] N.V. Voitovych, A.V. Naidonova, Vykorystannia khmarnykh tekhnolohii Google ta servisiv Web-2 v osvitnomu protsesi. Metodychni rekomendatsii. Dnipro: DPTNZ "Dniprovskyi tsentr PTOTS", 2017. Retrieved from https://fliphtml5.com/arbd/jejq/basic (in Ukrainian).

[10] V. Yu. Mihajlov "Osobennosti organizacii kontrolno-ocenochnoj deyatelnosti $v$ proces se obucheniya inostrannomu yazyku s ispolzovaniem servisa Google Classroom", Molodoj uchenyj, no. 3 (241), 2019. Retrieved from https://moluch.ru/archive/241/55723/ (in Russian).

[11] A.A.Zasluzhena "Dydaktyka dystantsiinoho navchannia", Dystantsiina osvita v Ukraini: innovatsiini, normatyvno-pravovi, pedahohichni aspekty, Accessed 15 July, 2020. Retrieved from

http://iiot.nau.edu.ua/images/docs/conference/conf_distance/16.06.2020/3бірка\%20tez_Dystant 
si ynaa\%20osvita_2020.pdf (in Ukrainian).

[12] Psihologija [Tekst] / pod red. V. N. Druzhinina :uchebnik dlja gumanitarnyh vuzov. 2-e izd. - SPb., 656 p., 2009.

[13] N. Doghonadze, A. A.,H. Halawachy, L.Knodel, A. S. Adedoyin, "The Degree of Readiness to Total Distance Learning in the Face of COVID-19 - Teachers' View (Case of Azerbaijan, Georgia, Iraq, Nigeria, UK and Ukraine)", Journal of Education in Black Sea Region Vol. 5, Issue 2, pp. 2- 41, 2020. DOI: 10.31578/jebs.v5i2.197

[14] Bower K. "Explaining motivation in language learning: a framework for evaluation and research", The Language Learning Journal, pp.558-574, 2017. .doi:10.1080/09571736.2017.1321035., [Scopus].

[15] S. Nurshahidah Sah Allam, M. Sufiean Hassan, R.Sultan. Mohideen, A. Faeza Ramlan, R. Mohd Kamal, "Online Distance Learning Readiness During Covid-19 Outbreak Among Undergraduate Students", International Journal of Academic Research in Business and Social Sciences, 10(5), pp. 642-657, 2020 DOI: 10.6007/IJARBSS/v10-i5/7

[16] Lukashenko I. "Psychological Aspects of Learning in Virtual Space". Visnik V.N. Karazin Kharkiv National University, A Series of Psychology. N. 60, pp. 40-43, 2016.

[17] Distance Learning in the Face of COVID-19 - Teachers' View (Case of Azerbaijan, Georgia, Iraq, Nigeria, UK and Ukraine)", Journal of Education in Black Sea Region Vol. 5, Issue 2, pp. 2-41, 2020. DOI: 10.31578/jebs.v5i2.197 